\title{
Hidden Engineers and Service Providers: Earthworms in Agricultural Land-Use Types of South Tyrol, Italy
}

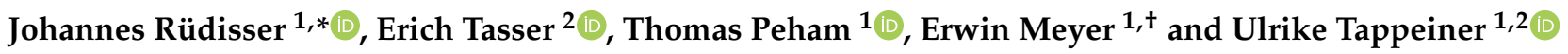 \\ 1 Department of Ecology, University of Innsbruck, Sternwartestr. 15, A6020 Innsbruck, Austria; \\ Thomas.Peham@tirol.gv.at (T.P.); Ulrike.Tappeiner@uibk.ac.at (U.T.) \\ 2 Institute for Alpine Environment, Eurac Research, Viale Druso 1, 39100 Bozen/Bolzano, Italy; \\ erich.tasser@eurac.edu \\ * Correspondence: Johannes.Ruedisser@uibk.ac.at; Tel.: +43-512-507-51617 \\ + E.M. deceased in June 2020.
}

Citation: Rüdisser, J.; Tasser, E.;

Peham, T.; Meyer, E.; Tappeiner, U. Hidden Engineers and Service Providers: Earthworms in Agricultural Land-Use Types of South Tyrol, Italy. Sustainability 2021, 13, 312 https://doi.org/10.3390/su13010312

Received: 7 October 2020 Accepted: 19 December 2020 Published: 31 December 2020

Publisher's Note: MDPI stays neutral with regard to jurisdictional clai$\mathrm{ms}$ in published maps and institutional affiliations.

Copyright: (C) 2020 by the authors. Licensee MDPI, Basel, Switzerland. This article is an open access article distributed under the terms and conditions of the Creative Commons Attribution (CC BY) license (https:// creativecommons.org/licenses/by/ $4.0 /)$.

\begin{abstract}
Earthworm activities affect the provision of many ecosystem services. Land use can strongly influence earthworm communities and, hence related soil functions. We assessed earthworm biomass, abundance, and species composition on grasslands, apple orchards, and vineyards in the context of an existing sustainability assessment tool in South Tyrol, Italy. A stratified sampling campaign revealed significant differences in earthworm distribution. We found 21 to 700 individuals $\mathrm{m}^{-2}$ in grasslands and surprisingly abundant earthworm communities in apple orchards (14 to 382 individuals $\mathrm{m}^{-2}$ ). Results for vineyards were ambiguous with no or very low abundance in $47 \%$ of the vineyards and a maximum of 396 individuals $\mathrm{m}^{-2}$. Mesohumic endogeic species were the most abundant functional group observed (75\% of the biomass in grasslands, $50 \%$ in apple orchards and vineyards). Aporrectodea caliginosa was the most abundant endogeic species, Lumbricus rubellus the dominant polyhumic endogeic species in all land-use types. We estimated a total of 34,900 $\mathrm{t}$ of earthworm biomass on agricultural areas in South Tyrol corresponding to a total value of EUR 872 million. Although soil quality is a complex concept that cannot be captured with a single indicator, earthworms are suitable and feasible indicators for sustainable soil use at the landscape scale.
\end{abstract}

Keywords: soil health; Lumbricidae; mapping; sustainability; functional trait; soil function; agriculture; landscape

\section{Introduction}

The impact of earthworms on physical, chemical, and biological soil properties was recognized very early in ecology (cf. [1]). Their role in pedogenesis and influence on key functions in most terrestrial ecosystems, which caused several earthworm species to be considered as "ecosystem engineers" [2], has been broadly studied with many different approaches [3]. While significant challenges to understand the detailed functional roles of distinct species and ecological groups remain [3], earthworms undoubtedly contribute to the development and maintenance of healthy soils through nutrient cycling, development of soil structure, change in drainage, interaction with other soil organisms and pollution remediation [4]. Therefore, various authors have proposed earthworms as indicators for soil health [5-7] and the assessment of sustainability in agricultural landscapes [8-10]. Earthworm activities can improve the productivity of these ecosystems and hence agricultural output: in a meta-analysis, including 58 studies around the world, crop yield increased on average $25 \%$ with the presence of earthworms [11]. Analysis by ecological earthworm groups showed that aboveground biomass increased with the presence of all groups, but the effect was strongest with presence of anecic species, species that dig permanent vertical burrows in which they drag leaves. Land-use type and soil management practice in agro-ecosystems can strongly influence the composition and abundance of earthworm communities and, hence their contribution to ecosystem processes [12-18]. 
Earthworm activities affect the provision of many ecosystem services (ES) such as increased soil fertility to cultivate crops, flood control, erosion control, soil restoration, provisioning of freshwater, and climate regulation [19]. The ES concept highlights the relation between ecosystems and human wellbeing. However, the contribution of soils and especially its biotic components are still underrepresented in ES assessments. ES frameworks, illustrating the contribution of soils to the supply of ES and related human profit and wellbeing, could promote sustainable land use and management practices and support an information-based decision making [20-22].

This is challenging because the interaction of soil living organisms with the abiotic part of the pedosphere, with the aboveground components of ecosystems [23], and with anthropogenic activities are manifold and can have both positive and negative feedbacks (Figure 1). Beside many key linkages between distinct earthworm species or functional groups and soil processes-and resulting ES [8,19] — the quantitative assessment of those ES still remains challenging [24]. Complex interactions among different earthworm species and with other biotic and abiotic components of the ecosystem [25] cause divergent, synergetic, and nonlinear effects of different earthworm species on ES. Furthermore, ES demand may be different in different land-use types. The use of functional groups with similar traits as ecosystem service providers (ESP) can help to facilitate this inherent complexity $[15,21,26,27]$. We therefore apply functional earthworm groups (as described in 2.2) as ESP to identify and communicate ES provided by earthworms.

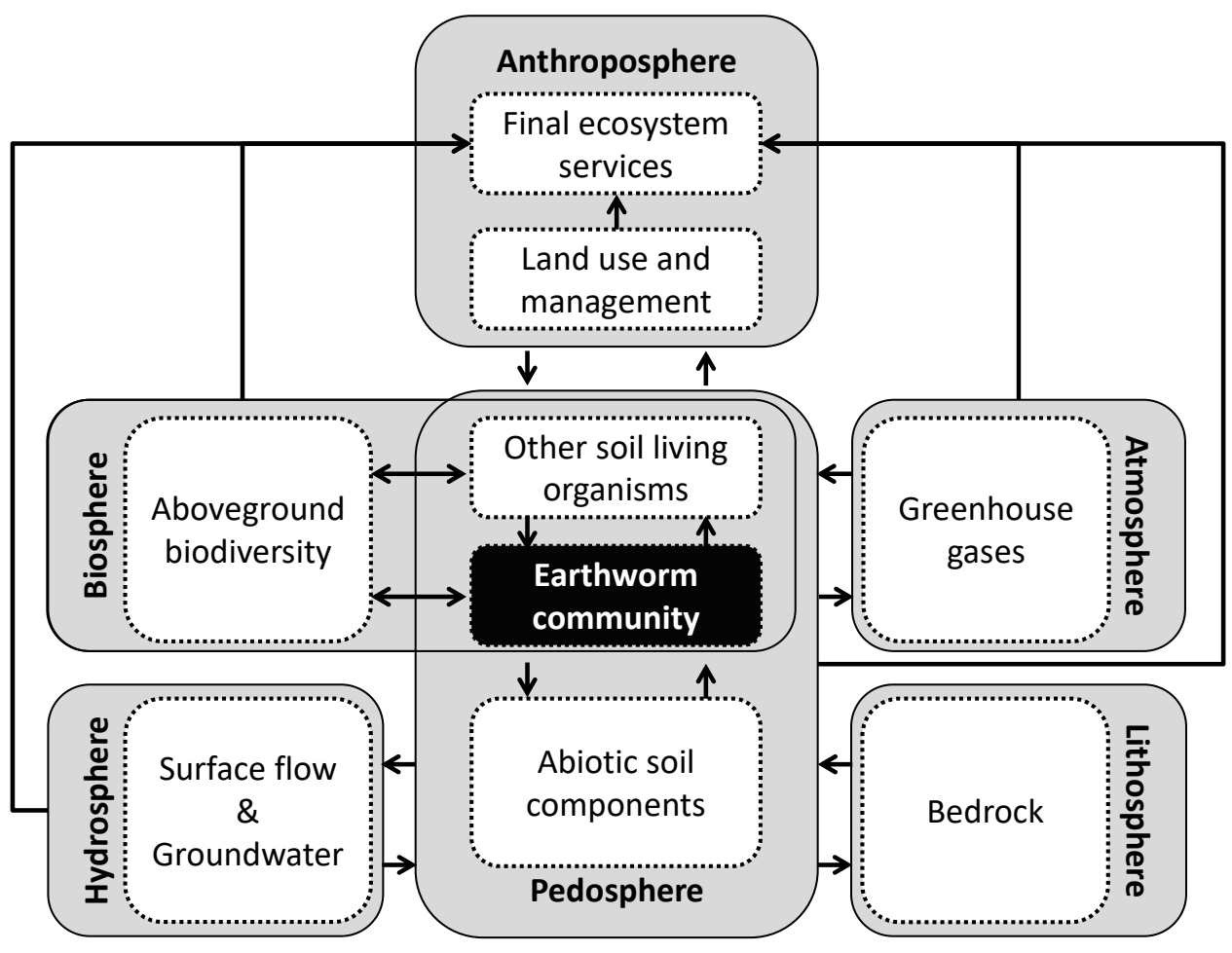

Figure 1. Conceptual framework of the interaction of earthworms with the abiotic part of the pedosphere, the aboveground components of ecosystems, and anthropogenic activities.

Hence, the goal of this study was to assess earthworm communities on the predominantly agricultural land-use types (grassland, apple orchards and vineyards) in South Tyrol (Italy) to estimate and communicate their contribution to the provision of ES. We used abundance and biomass of functional earthworm groups, as well as species richness and Shannon's diversity index, as indicators for earthworm related ES and hence sustainable soil use on different land-use types. The use of earthworm species richness and Shannon's diversity index is based on the consideration that ecological stability increases in more diverse ecosystems $[15,28]$, and also accounts for the observation that cumulative impacts 
of different functional earthworm groups can lead to improved agricultural productivity $[18,29,30]$. Additionally, we used a straightforward approach to assess the economic value of earthworm communities and their yearly contribution to topsoil production based on market prices for earthworms or soil, respectively. Finally, we discuss the potential outcomes and limitations of the approach.

\section{Materials and Methods}

\subsection{Study Site and Field Sampling}

South Tyrol is situated in the northern part of Italy, in the Central Alps. It covers an area of $7399 \mathrm{~km}^{2}$ and is divided in 116 municipalities. The smallest municipality covers $1.6 \mathrm{~km}^{2}$ and the largest $302.3 \mathrm{~km}^{2}$. The total area used for agriculture is $2405 \mathrm{~km}^{2}$. The predominant agricultural land-use types are mountain pastures $(61 \%)$, hay meadows $(27 \%)$, apple orchards $(8 \%)$, and vineyards $(2 \%)$ [31]. We took stratified samples on the three predominant land-use types below $1500 \mathrm{~m}$ above sea level which are hay meadows $(n=15)$, apple orchards $(n=20)$, and vineyards $(n=15)$ (Figure 2$)$. Site selection aimed at representatively depicting the habitat variability within each land-use type. Hay meadows management ranged from extensively managed (with only one cut per year) to intensively managed (with two to three cuts per year). Management in vineyards and apple orchards included integrated fruit production systems as well as cultivation according to organic standards. Mulching of the grass verge was done in all apple orchards and vineyards. All orchards were irrigated while in the other two land-use types there were both irrigated and non-irrigated sites. The corresponding land use was present for at least 10 years, but mostly much longer. Soil types at the sites were either Cambisol $(n=44)$ or Leptosol $(n=6)$ according to the world reference base for soil resources [32].

At each site, soil samples were taken in the spring and autumn. For this, a soil core of $30 \mathrm{~cm}$ diameter and $15 \mathrm{~cm}$ depth was drilled out and transported in a cotton bag to the laboratory. There, the soil core was divided into two layers $(0-7.5 \mathrm{~cm}$ and $7.5-15 \mathrm{~cm})$ and placed in an adapted Kempson-extractor [33] within $24 \mathrm{~h}$. The samples were kept therein for up to 14 days until they were completely dry. The extracted earthworms were transferred from the fixation solution (picric acid) into ethanol (75\%). Abundance and biomass of earthworms were expressed as $\mathrm{n} \mathrm{m}^{-2}$ and $\mathrm{g} \mathrm{m}^{-2}$, respectively. Prior to the data analysis, annual mean values for each site were calculated based on the spring and autumn samplings. For more details on the sampling protocol see Rüdisser et al. [34].

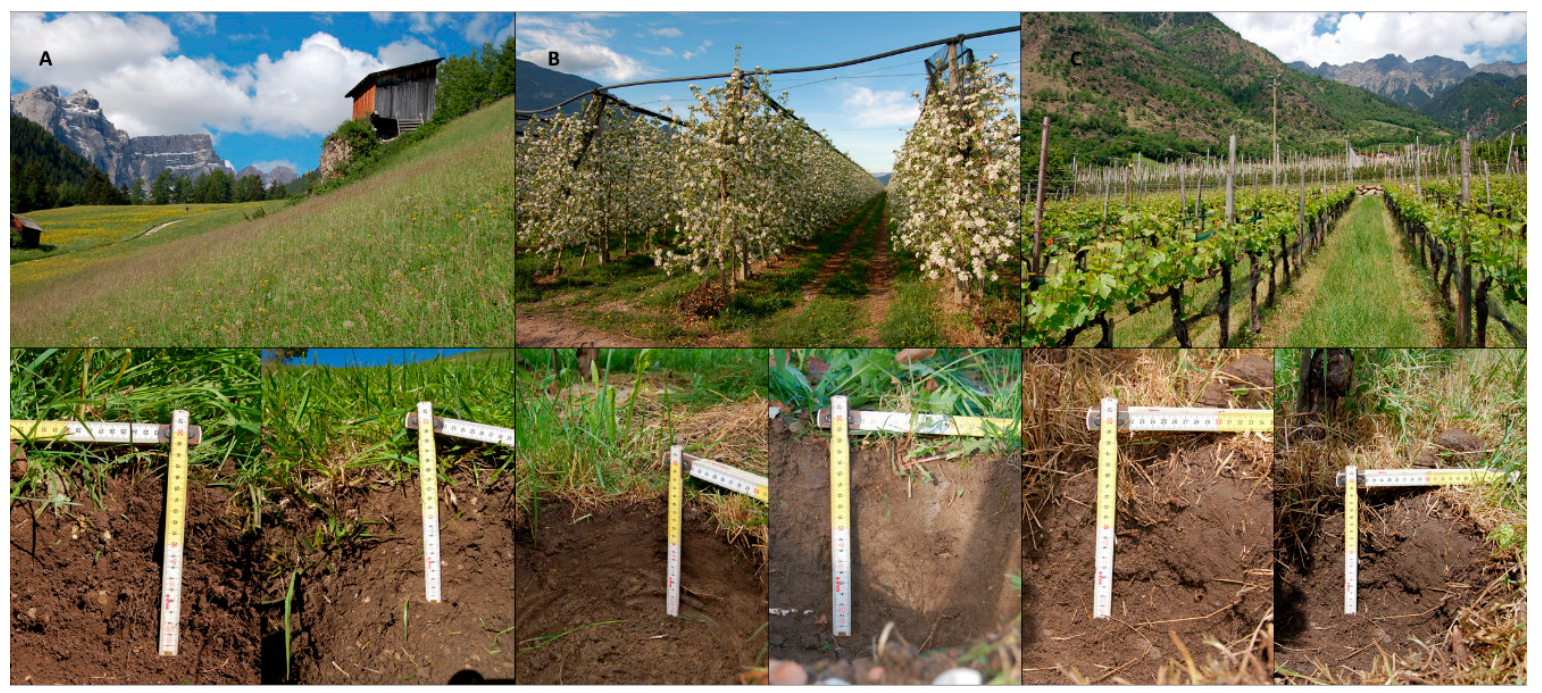

Figure 2. Exemplary pictures from field samplings in the three investigated land-use types (A) hay meadows, (B) apple orchards, and (C) vineyards and pictures of the corresponding sampling holes. 


\subsection{Functional Earthworm Groups and Ecosystem Services}

For the assessment and mapping of ES, it has been proven useful to structure and visualize the chain from ecosystems to human wellbeing along a theoretical cascade $[35,36]$. This cascade model distinguishes five sequential categories: (1) ecosystem structures and processes, (2) functions, (3) services, (4) benefits, and (5) values. While the first two categories are related to the bio-physical characteristics of an ecosystem, the last two focus on the benefits that ecosystems provide to people, and, hence, are embedded in the particular socio-economic context. We applied the ES cascade model in line with Keith and Robinson [19] to describe the relation between earthworm activities and the provision of ES from agricultural soils (Figure 3). To structure the large number of soil processes contributing to ES, Kibblewhite et al. [7] proposed to aggregate biological processes in soils in four ecosystem functions that support all major ES provided by soils. We used these aggregated functions (carbon transformation, nutrient cycling, soil structure maintenance, and biological population regulation) and related them to both the predominant activities of different functional earthworm groups and correspondent ES. While the used ES nomenclature is in line with the Common International Classification of Ecosystem Services (CICES v5.1; http:/ / cices.eu/), we did not distinguish between final or intermediate ES [37,38], because this distinction is often observer-based and case-dependent $[39,40]$.

\begin{tabular}{|c|c|c|c|c|}
\hline \multicolumn{2}{|c|}{ Biophysical structures and processes } & $\begin{array}{l}\text { Aggregated ecosystem } \\
\text { functions }\end{array}$ & $\begin{array}{l}\text { Ecosystem services } \\
\text { (CICES classification) }\end{array}$ & Benefits (Examples) \\
\hline \multirow{2}{*}{$\begin{array}{l}\text { Epigeic } \\
\text { Bimastos parvus } \\
\text { Dendrobaena octaedra } \\
\text { Dendrobaena pygmaea } \\
\text { Dendrodrilus rubidus }\end{array}$} & \multirow{2}{*}{$\begin{array}{c}\text { Transport, fragment and } \\
\text { decompose organic } \\
\text { matter }\end{array}$} & \multirow[b]{2}{*}{ Nutrient cycling } & & Foed or income \\
\hline & & & $\begin{array}{l}\text { Decomposition and } \\
\text { fixing processes }(R)\end{array}$ & Reduced costs \\
\hline \multirow{2}{*}{ Lumbricus terrestris } & \multirow{2}{*}{$\begin{array}{l}\text { Influence the growth of } \\
\text { microorganisms }\end{array}$} & \multirow{2}{*}{$\begin{array}{l}\text { Biological population } \\
\text { regulation }\end{array}$} & $\begin{array}{l}\text { Pest and disease control } \\
\text { (R) }\end{array}$ & Reduced costs \\
\hline & & & $\begin{array}{l}\text { Habitat and gene pool } \\
\text { protection }(R)\end{array}$ & Future possibilities \\
\hline \multirow{2}{*}{$\begin{array}{c}\text { Endogeic polyhumic } \\
\text { Lumbricus castaneus } \\
\text { Lumbricus rubellus }\end{array}$} & $\begin{array}{l}\text { Build burrows and } \\
\text { tunnels }\end{array}$ & \multirow{3}{*}{$\begin{array}{l}\text { Pedogenesis and soil } \\
\text { structure maintenance }\end{array}$} & $\begin{array}{l}\text { Soil formation and } \\
\text { composition }(R)\end{array}$ & $\begin{array}{l}\text { Fertile soils for } \\
\text { agriculture }\end{array}$ \\
\hline & \multirow{3}{*}{$\begin{array}{c}\text { Form complex mineral- } \\
\text { organic-aggregates }\end{array}$} & & $\begin{array}{l}\text { Mass stabilisation and } \\
\text { erosion control }(\mathrm{R})\end{array}$ & Damage prevention \\
\hline $\begin{array}{l}\text { Aporrectodea caliginosa } \\
\text { Aporrectodea chlorotica }\end{array}$ & & & $\begin{array}{l}\text { Water flow maintenance } \\
\qquad(\mathrm{R})\end{array}$ & $\begin{array}{c}\text { Prevention of extreme } \\
\text { events }\end{array}$ \\
\hline $\begin{array}{l}\text { Aporrectodea rosea } \\
\text { Octolasion lacteum } \\
\text { Proctodrilus antipai }\end{array}$ & & Carbon transformation & Climate regulation $(\mathrm{R})$ & Climate regulation \\
\hline
\end{tabular}

Figure 3. The ecosystem service cascade based on Haines-Young and Potschin [35] applied to illustrate the key relationships between the main activities of functional earthworm groups, soil functions, ecosystems services, and human benefits [19]. Ecosystem functions are aggregated as proposed by Kibblewhite et al. [7]. The mentioned earthworm species are those registered in the case study. ( $R=$ regulating service, $P=$ provisioning service).

Earthworm species vary in their morphology, activity, and feeding behavior and are generally divided into ecological life types, namely epigeic (litter inhabitants), anecic (vertical burrowers) and endogeic (mineral dwellers) species [41,42]. These ecotypes or functional groups can be seen as an early application of a trait-based approach as defined by Webb et al. [43]. The contribution of functional earthworm groups to specific ecosystem functions and subsequent ES are often complementary and overlapping [44], nevertheless 
predominant associations can be identified (corresponding CICES v5.1 class codes are mentioned in brackets):

Epigeic species live in the topsoil and mainly feed on litter and the attached microflora. They strongly influence the decomposition of organic matter as well as nutrient cycling by increasing the available surface and interacting with other soil organisms $[4,31]$. These soil functions are associated with ES such as detoxification (CICES 2.1.1.1), waste disposal (CICES 2.1.1.1), pest control (CICES 2.3.2.1), and-finally yet importantly-increase soil fertility to cultivate crops (CICES 2.2.4.1). Furthermore, the activities of epigeic earthworms in the topsoil can affect the roughness of the soil surface and increase infiltration rates (CICES 2.2.1.3) [16].

Endogeic species live and feed within the soil and make horizontal or randomly oriented burrows [45]. Based on their feeding behavior, endogeic species can be further subdivided in polyhumic endogeic species that feed on soil with high organic matter content, mesohumic endogeic species that feed on both mineral and organic particles in the soil, and oligohumic endogeic species that mainly occur in deeper horizons of tropical soils feeding on low quality soil organic matter supported by mutualistic associations with microflora [46-49]. Because endogeic earthworm activities stimulate the growth of plant roots and microbes and induce the decomposition of organic matter [50], they mainly influence ecosystem functions related to soil structure maintenance and biological population control. These soil functions are a precondition for various ES such as water flow maintenance (CICES 2.2.1.3), clean water provision (CICES 2.2.5.1), mass stabilization and control of erosion rates (CICES 2.2.1.1), weathering processes (CICES 2.2.3.2), decomposition and fixing processes (CICES 2.2.4.2), and support the cultivation of crops (CICES 1.1.1.1).

Anecic species build permanent vertical burrows that substantially contribute to the water flow regulation in soils. Their abundance and biomass correlate with the occurrence of large macropores which are associated with a rapid and deep-water infiltration rate [51,52], and they can counteract the effect of intense rain events on soil and plants [53]. A meta-analysis showed that anecic earthworms increase water infiltration significantly [16]. Furthermore, they translocate large amounts of leaves into the soils and hence contribute to the decomposition process and the building of complex soil aggregates [25,49]. Together with the endogeic species, they support the provision of ES associated with water flow maintenance (CICES 2.2.1.3), decomposition and fixing processes (CICES 2.2.4.2), as well as mass stabilization and control of erosion rates (CICES 2.2.1.1).

\subsection{Economic Value of Earthworm and Related Ecosystem Services}

We estimated the value of the natural capital consisting of earthworms living in agricultural soils based on market prices for vermiculture products. Market prices for earthworms (based on an online survey done in September 2020) ranged from EUR 25 to EUR 65 for 1000 averagely sized worms (mostly the epigeic Dendrobaena sp.). This corresponds to approximately $1 \mathrm{~kg}$ of worms. We estimate the total value of all earthworms on agricultural fields in the study area by multiplying their estimated biomass per $\mathrm{m}^{-2}$ with the area of the respective land-use type and the lowest market price (EUR 25). Additionally, we valued the ES soil formation as proposed by Porter et al. [54] and Sandhu et al. [55] based on the assumption that earthworms form the same amount of soil per year as their own biomass. Hence, we calculated the value of topsoil created by multiplying total earthworm biomass by the price of topsoil. We used EUR $26 \mathrm{t}^{-1}$ as price for topsoil.

\subsection{Statistical and Spatial Analysis}

Differences in earthworm abundance, biomass, species richness, and Shannon's diversity index for the land-use types hay meadow, apple orchard, and vineyard were analyzed with one-way ANOVA followed by Fisher's Least Significant Difference (LSD) test $(p=0.05)$. Shannon's diversity index $H^{\prime}$ was calculated as follows: $H^{\prime}=-\sum$ pi $\ln (\mathrm{pi})$, where $\mathrm{pi}$ is the proportion of the biomass of species i relative to the total biomass of species in the dataset. Earthworm biomass and indicator estimations for municipalities were 
based on a set of different land-use data: LAFIS-data (which are part of the Integrated Administration and Control System (IACS) of the European Commission), data from the National "Agenzia per le Erogazioni in Agricoltura" (AGEA), and the digital land-use map of the Autonomous Province of South Tyrol (2001). All data were merged to a new raster with a cell size of $5 \mathrm{~m}$ [26]. This raster was used for spatial analysis. As one goal of our case study was the statewide estimation of earthworm biomass and abundance on agricultural areas per municipality in South Tyrol, we limited our analysis to these land-use types. Soil type was not considered because, until now, no detailed and spatially comprehensive soil map exists for the study area, and our representative sampling mainly included samplings on Cambisols $(n=44)$ and only few Leptosols $(n=6)$. Therefore, we estimated the total earthworm biomass for South Tyrol using the average biomass values per land-use type and the spatially most relevant agricultural land-use types in South Tyrol. All statistical analyses were performed with PASW Statistics 18. GIS tasks were performed in ArcGIS 10.

\section{Results}

Earthworm abundance, biomass, species richness, and Shannon's diversity varied significantly across investigated land-use types (ANOVA, $p<0.05$ ). All the parameters were the lowest in vineyards (LSD, $p<0.05$ ). However, no significant differences between hay meadows and apple orchards could be found (Table 1).

Table 1. Mean values of earthworm abundance, biomass, species richness, and Shannon-Wiener index $\left(H^{\prime}\right)(n=$ number of sample sites; \pm standard deviation; letters $(\mathrm{a}, \mathrm{b})$ identify significant differences (ANOVA, $p<0.01$ and LSD, $p<0.01$ ) between land-use types).

\begin{tabular}{cccccc}
\hline Land-Use Type & $\boldsymbol{n}$ & Abundance $\left(\mathbf{n ~ m}^{-\mathbf{2}}\right)$ & Biomass $_{\left(\mathbf{g ~ m}^{-\mathbf{2}}\right)}$ & Species Richness $^{H^{\prime}}$ \\
\hline Hay meadows & 15 & $239 \pm 185^{\mathrm{a}}$ & $40.2 \pm 31.5^{\mathrm{a}}$ & $3.3 \pm 1.4^{\mathrm{a}}$ & $1.2^{\mathrm{a}}$ \\
Apple orchards & 20 & $208 \pm 108^{\mathrm{a}}$ & $43.1 \pm 28.7^{\mathrm{a}}$ & $3.6 \pm 1.3^{\mathrm{a}}$ & $1.2^{\mathrm{a}}$ \\
Vineyards & 15 & $83 \pm 118^{\mathrm{b}}$ & $17.3 \pm 34.5^{\mathrm{b}}$ & $1.2 \pm 1.3^{\mathrm{b}}$ & $0.4^{\mathrm{b}}$ \\
\hline
\end{tabular}

As indicated by the high standard deviations (Table 1), variability of earthworm abundance and biomass was very high. It ranged from 21 to 700 individuals $\mathrm{m}^{-2}$ in hay meadows, from 14 to 382 individuals $\mathrm{m}^{-2}$ in apple orchards, and from zero to 396 individuals $\mathrm{m}^{-2}$ in vineyards. In seven ( $47 \%$ ) of the investigated vineyards no single earthworm was observed neither in the spring nor in the autumn sampling. Proportion of functional earthworm groups also differed between the investigated land-use types (Figure 4). Mesohumic endogeic species were the most abundant functional group observed. The mesohumic endogeic species Aporrectodea caliginosa, Octolasion lacteum, and Aporrectodea rosea comprised on average $75 \%$ of the total earthworm biomass in hay meadows. Aporrectodea caliginosa, Octolasion lacteum, Aporrectodea rosea and Allolobophora chlorotica comprised 50\% of the total earthworm biomass in apple orchards, and Aporrectodea caliginosa, Octolasion sp, and Aporrectodea rosea $50 \%$ of the total biomass in vineyards. Aporrectodea caliginosa was the most abundant endogeic species in all three land-use types. However, mesohumic endogeic species were absent in nine (60\%) vineyards and in one $(7 \%)$ apple orchard. Lumbricus rubellus was the dominant polyhumic endogeic species in all land-use types. Polyhumic endogeic species were absent in seven (47\%) vineyards, and in two $(10 \%)$ of the investigated apple orchards. Except for the seven vineyards where no earthworms were observed, endogeic species (either polyhumic or mesohumic) could be observed at all sampling sites. The epigeic species Dendrobaena octaedra and Dendrodrilus rubidus both occurred in hay meadows and apple orchards, while Bimastos parous — an introduced species originally endemic in North America-was found only in apple orchards. Epigeic species were absent in $13(86 \%)$ vineyards, in $6(30 \%)$ apple orchards, and at $10(67 \%)$ sampling points in hay meadows. The only observed anecic earthworm species Lumbricus terrestris was present in two $(10 \%)$ apple orchards and in two (13\%) vineyards. At all other locations, including all 
observed hay meadows, no adult anecic earthworms could be found. For detailed results on species level, see Table S1.

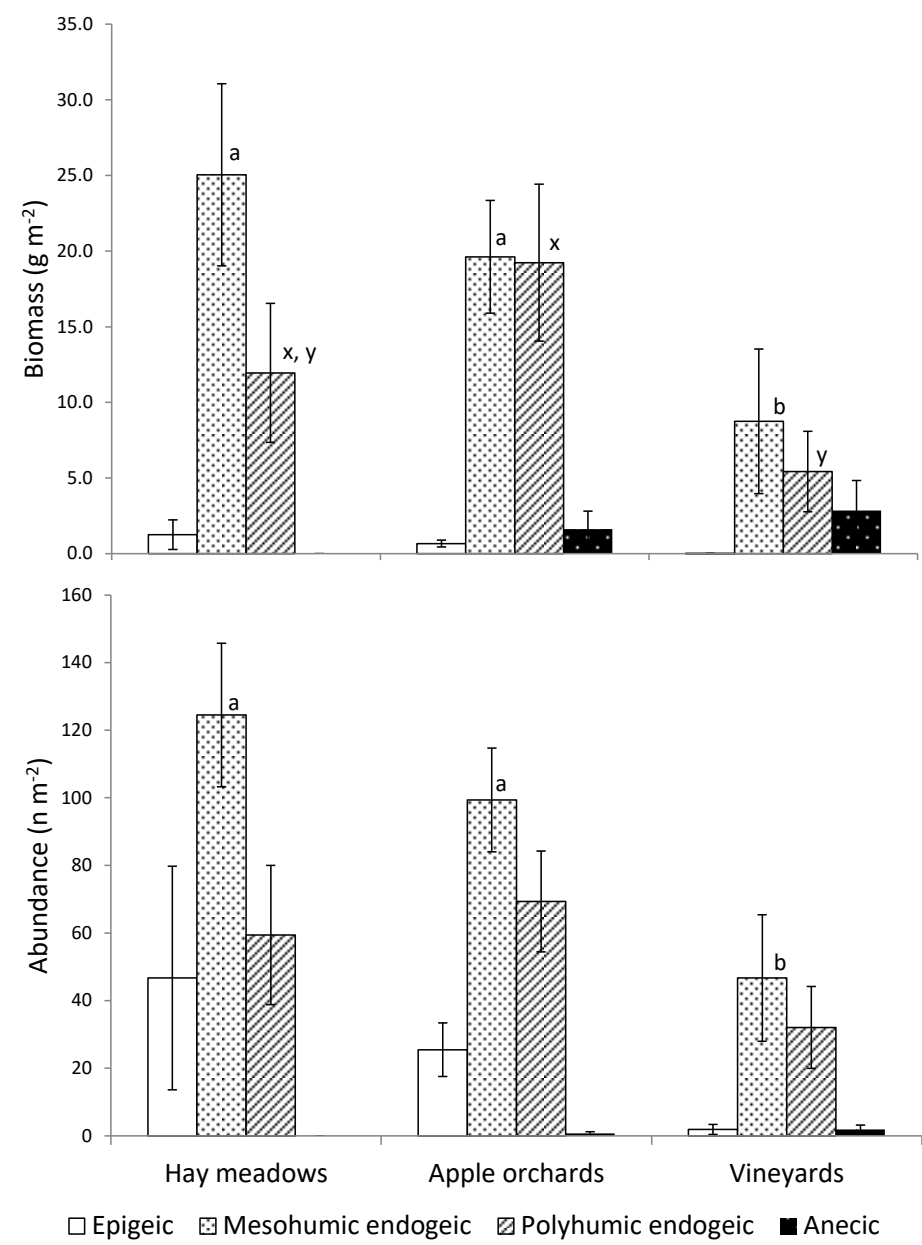

Figure 4. Abundance and biomass of functional earthworm groups for the three predominant landuse types in South Tyrol. Error bars indicate the standard error. Letters $(a, b ; x, y)$ identify significant differences (ANOVA, $p<0.05$ and LSD, $p<0.05$ ) between land-use types.

Based on average earthworm biomass per land-use type, we estimated a total of $34,900 \mathrm{t}$ of earthworm biomass on agricultural areas in South Tyrol (below 1500 m.a.s.l), or 26,000 $t$ (being 25,143 $t$ endogeic and $856 \mathrm{t}$ epigeic species) on hay meadows, $8000 \mathrm{t}$ (being $7554 \mathrm{t}$ endogeic, $316 \mathrm{t}$ anecic and $130 \mathrm{t}$ epigeic species) on apple orchards, and $900 \mathrm{t}$ (being $749 \mathrm{t}$ endogeic, $151 \mathrm{t}$ and $0.5 \mathrm{t}$ epigeic species) on vineyards. Average earthworm biomass on agricultural areas was highest in municipalities where apple orchards and hay meadows are the predominant land-use type. In contrast, municipalities dominated by vineyards achieved the lowest values (Figure 5).

Applying the lowest market price paid for earthworms in the context of vermiculture application, the earthworm population in the agricultural areas in South Tyrol corresponds to a total value of EUR 872 million, or EUR 650 million in hay meadows, EUR 200 million in apple orchards, and EUR 22 million in vineyards. These earthworms form a total of $34,900 \mathrm{t} \mathrm{a}^{-1}$ of new topsoil in the agricultural area of South Tyrol which has a yearly value of EUR 907,400. 


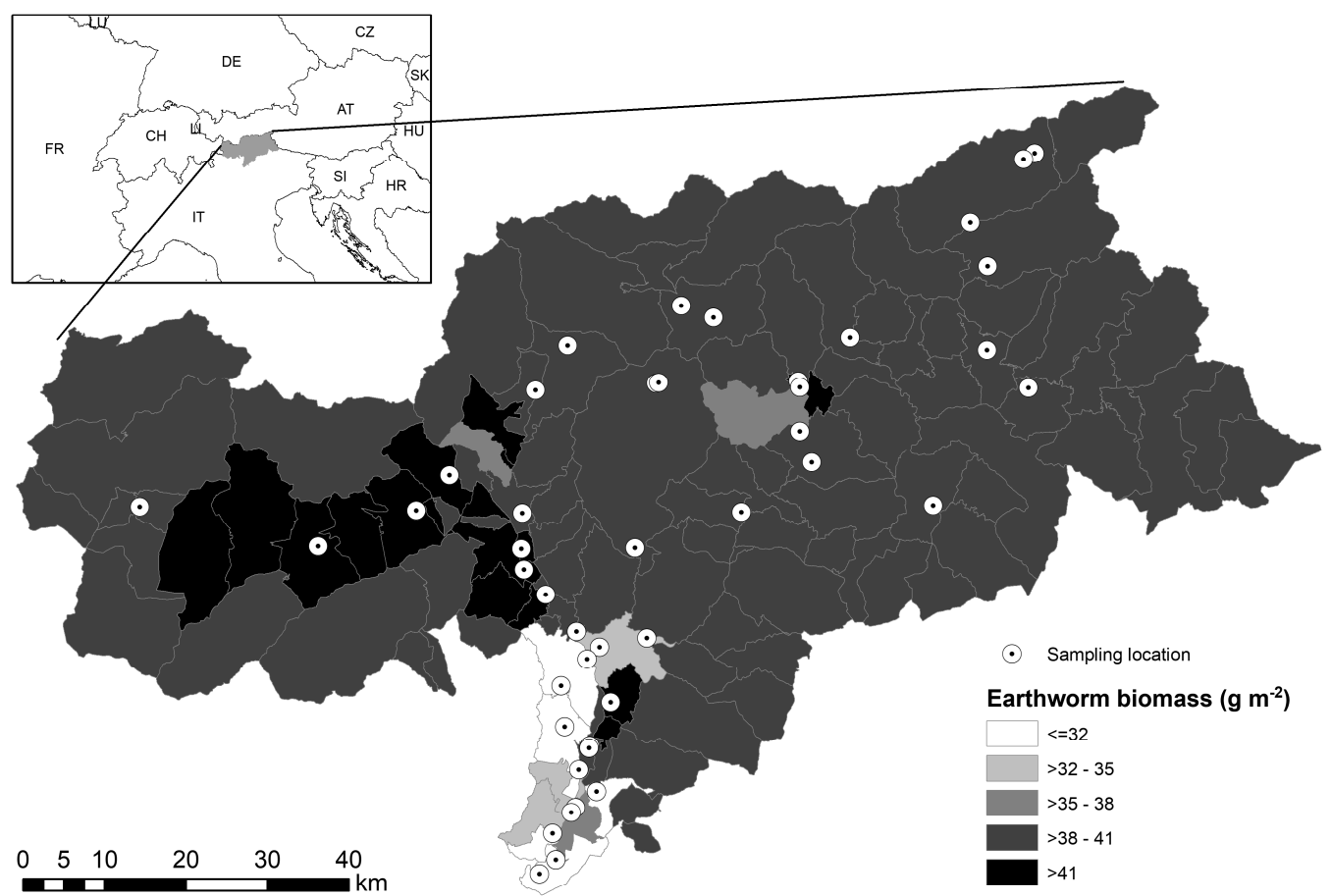

Figure 5. Average earthworm biomass on agricultural used areas per municipality in South Tyrol.

\section{Discussion}

\subsection{Land-Use and Earthworm Communities}

While we expected to encounter vital earthworm communities in grasslands, we also found surprisingly abundant and diverse earthworm communities in apple orchards. Results for vineyards were ambiguous, as we encountered relatively high abundance values at some sites but no earthworms at many other sites. Earthworm abundance and biomass in hay meadows and apple orchards are considerably higher than in mixed deciduous forests, representing the naturally occurring vegetation in the study region (Meyer, unpublished data). The high variability of earthworm abundance within the investigated land-use types and especially the high number of sites where one or more functional earthworm groups were missing indicate a relevant potential to apply more earthworm-friendly management practices. This could foster earthworm population and help to improve the sustainability of land use $[11,25,56]$.

The regular mulching applied in many apple orchards together with the fairly constant soil humidity due to regular irrigation seems to promote soil fauna [34]. However, earthworms living in orchards, which are amongst the most treated agricultural crops in the European Union, are potentially exposed to a high amount of pesticides [44]. A comparison between integrated and organic managed apple orchards revealed that organic managed systems reached a significantly $(p<0.05)$ higher average total earthworm biomass of 53.9 $( \pm 15.6) \mathrm{g} \mathrm{m}^{-2}$ (5 sites) compared to $39.5( \pm 6.9) \mathrm{g} \mathrm{m}^{-2}$ in integrated managed systems (10 sites). Furthermore, anecic earthworms did only occur in organic apple orchards or organic vineyards except for one conventional vineyard where an exceptional high earthworm abundance of $135 \mathrm{~g} \mathrm{~m}^{-2}$ was recorded. Our study did not focus on management differences within land-use types, and therefore, the number of sampling sites in organically managed fields was low. However, our findings are in line with Paoletti et al. [13] and Van Zwieten et al. [57] who observed that soils contaminated with pesticides, which are frequently applied in many orchards and vineyards are often avoided by earthworms. Particularly copper, which often can be found in high concentration in vineyards, has a strong inhibiting effect on endogeic and anecic earthworms $[13,58]$. Plant cover and its management is another important factor influencing earthworm communities in perennial cultures [59]. Growing cover crops or keeping native vegetation in vineyard does not only 
promote earthworm communities [60] but benefits biodiversity in general [61]. Therefore, the use of herbicide such as glyphosate to reduce the water and nutrient competition in perennial fruit cultures can effect earthworm communities negatively by both direct and indirect effects [62-64]. The generally dryer soil conditions in vineyards compared to apple orchards might be another reason for the reduced earthworm abundance. The observed high variability of the earthworm communities within land-use types is a common phenomenon in soil ecosystems and indicated a possibility to improve soil quality in fields with low values $[5,65]$.

While land-use type and management practice, as well as climatic conditions, mainly determine the characteristic of earthworm communities at the regional scale, soil parameters such as $\mathrm{pH}$-value, soil organic matter content, clay content and soil texture can affect its composition at the field scale [66,67]. Jänsch et al. [68] who analysed data from 294 sites in Germany determined land-use type inter-correlated with $\mathrm{pH}$-value as the main factor influencing occurrence and abundance of earthworms. In our case we focus on the influence of land-use type and soil management practice as the most relevant anthropogenic factors influencing earthworm communities. This is in line with Tsiafouli et al. [69] who found a decreasing earthworm species richness with increasing land-use intensity and De Vries et al. [70] who observed a strong impact of land-use intensity on the structure of soil food webs and related ES in Europe. Furthermore, they observed that the predictive power of soil-food web structure was of comparable importance as the investigated abiotic factors [70].

\subsection{Earthworm as Indicator for Sustainable Land Use}

A better understanding of how visible soil organisms contribute to processes and ES in agroecosystems, and why they are good indicators for soil quality, can improve decisionmaking processes related to land-use management [71,72]. Velasquez and Lavelle [73] therefore promote indicators based on macroinvertebrate communities which can be explored relatively easily and with low costs and, hence enable farmers to assess soil quality and soil-based ES. Paoletti et al. [13] and Turbé et al. [10] proposed to use earthworms as bioindicators in agroecosystems. While several countries already use earthworm assessment as part of monitoring programs of soil quality [74,75], its use as an indicator for related ES is still in its infancy. Nevertheless, soil experts, who were asked to rate the indicative value of 50 biological soil parameters for corresponding ES, rated abundance and diversity of earthworms very highly [17]. However, the use of earthworms as biological indicators for a European soil monitoring may be limited by the fact that earthworms are not ubiquitous in all European bio-geographical zones [76,77]. Rutgers et al. [78] predicted earthworm distribution across Europe and proposed to use the derived maps as a starting point for soil-related ES assessments.

Earthworms are part of a multifaceted ecological web with complementary and antagonistic species and guilds. Although many ES are clearly related to earthworm activities, and while some authors have tried to quantify the contribution of individual earthworm species or functional groups to the provision of distinct ES on the basis of experimental studies [79], it appears nearly impossible to quantify their exact contribution for all ES at the landscape scale. Schon et al. [80], who investigated carbon incorporation by different functional groups of earthworms in a mesocosm study, concluded that all three earthworm functional groups should be present in soils to maximize incorporation of carbon from dung deposit on the soil surface. The same is true for crop yields. Both, Johnston et al. [25] and van Groenigen et al. [11], who used literature data to model the relationship between earthworm population biomass and crop yield, estimated that earthworm presence led to an average $28 \%$ and $25 \%$ increase, respectively. In mesocosm experiments plant growth and earthworm abundance had a strong positive correlation resulting in an average increased growth of $30 \mathrm{~g} \mathrm{~m}^{-2}$ for every 100 earthworms [79]. However, all authors indicate that specific mechanisms and underlying relationships between functional earthworm groups and plant production remain unclear, and that the 
multiple feedbacks and dynamic interactions between soil organisms and the physical environment hinder exact predictions.

To quantify individual ES one has to establish the biophysical relationship between functional earthworm groups and the functions they provide as described with two examples by Pascual et al. [81]. We deliberately withstood to quantify individual ES based on the study data because we feel that until now, there are not sufficient published data to quantify all earthworm related ES at the landscape levels under real-world conditions. Furthermore, the multiple feedbacks and dynamic interactions between soil organisms and the physical environment hinder exact predictions. This is a drawback because it hampers a straightforward communication of the important contribution of earthworm populations to agricultural production in specific, as well as human wellbeing in general [62]. To overcome this drawback we used biomass, abundance, and diversity of functional earthworm groups as surrogate indicators to determine the natural capital, and hence potential ES [81,82]. This is supported by the results of a meta-analysis conducted by Pascual et al. [81] focusing on the effect of earthworms on water infiltration rates: while farming system (conventional, reduced, or no tillage), land-use type, and the average number of earthworms were significant predictors of water infiltration rates, earthworm number accounted for $61 \%$ of the observed variation. However, this generalizing approach, which is important and helpful to communicate the value of soil biodiversity to policy makers and the general public $[83,84]$, can and should be complemented by detailed quantification of selected ES or ES bundles as proposed by Haida et al. [21].

\subsection{ES and Economic Valuation}

Documenting the economic value of ES or natural capital can help to highlight the importance of unseen or neglected ES and to communicate this value using a familiar reference such as monetary unites. Today, various economic valuation methodologies exist. Robinson et al. [85] reviewed examples of valuation of soils and Dominati et al. [86] presented a detailed framework to quantify and value the contribution of soils to the provision of ES from agro-ecosystems at the field scale. We deliberately complemented the assessment of earthworm biomass, abundance, and species composition with a simple economic valuation of both the natural capital in form of total earthworm biomass as well as the flow of one ES (topsoil production). Porter et al. [54] and Sandhu et al. [55] valued the ES soil formation by the average amount of topsoil created by earthworms. If this topsoil is not used directly or lost through erosion, one could argue that topsoil production represents an intermediate ES [37]. Topsoil production could also be seen as a contribution of earthworms to create natural capital, further supporting ESs. Therefore, the estimated values might even underestimate the contribution of earthworms to ES. Direct market valuation is a broadly applied valuation technique for ES that corresponds mainly with goods or products. It uses the exchange value of those goods in trade to estimate the economic importance of a given good or service [87]. Nevertheless, our straightforward economic valuation should only complement our approach to illustrate and communicate the contribution of earthworms to human wellbeing and its tremendous value as natural capital, but it should not be used as basis for cost-benefit analysis [88].

\subsection{Conclusion and Outlook}

The observed earthworm communities and the assessment of related ecosystem services delineates the important role earthworms play in agriculture. Our study provides a starting point to integrate field data on earthworm abundance and community composition in ecosystem service and natural capital assessments on the landscape scale. While soil quality is a very complex issue that neither can be captured with a single indicator nor should be seen isolated from environmental quality in general, there is a need for feasible and comprehensible indicators for soil quality that can be used by stakeholders to improve decision-making processes related to land use. The major relationship between ecosystem services and functional earthworm groups, the comparatively easy sampling 
methodology, and a positive public image designate earthworm community characteristics as suitable indicators for this task. Significant differences between the investigated land-use types and the high variability within indicate not only the importance to promote earthworm-friendly management practices but highlights also the demand for further (field) studies to establish sound reference values for different management practices and soil types. Such assessments could profit from the involvement of non-specialists in scientific research as demonstrated by the international citizen science project "Earthworm Watch" (http:/ / earthwormwatch.org). Involving citizens in environmental monitoring activities is not only a possibility to facilitate comprehensive assessments, but also an effective way to increase the public understanding, and commitment for issues related to biodiversity protection.

Supplementary Materials: The following are available online at https:/ / www.mdpi.com/2071-105 0/13/1/312/s1, Table S1: Biomass of earthworm species for the three predominant land-use types in South Tyrol.

Author Contributions: Conceptualization, J.R., U.T. and E.T.; methodology and investigation, all authors; laboratory and species identification, T.P.; formal analysis, J.R.; writing-original draft preparation, J.R.; writing-review and editing, all authors; visualization, J.R.; E.M. deceased in June 2020. All authors have read and agreed to the published version of the manuscript.

Funding: This research was funded by the Autonomous Province South Tyrol (Abteilung Bildungsförderung, Universität und Forschung) and the HSMR project KLIMAGRO financed by the Federal Ministry of Science, Research and Economy.

Institutional Review Board Statement: All samples were collected according to the Südtiroler Naturschutzgesetz (L.G. 12. 5. 2010). Ethical review and approval were waived for this study, as no vertebrate animals were involved.

Informed Consent Statement: Not applicable.

Data Availability Statement: The data presented in this study are available on request from the corresponding author.

Acknowledgments: We wish to thank the Farmer Association of South Tyrol (Südtiroler Bauernbund), as well as all farmers involved, for supporting and facilitating our fieldwork. The project SOILDIV: Biodiversity of soil macro-fauna as indicator of biological soil quality-supplementing the indicators for a sustainable development in South Tyrol (2011-2013) aimed to develop a methodology to evaluate and assess biological soil quality in the context of a state-wide sustainability assessment for the Autonomous Province South Tyrol (www.sustainability.bz.it). J.R., and U.T. are members of the 'Research Area Mountain Regions' at the University of Innsbruck. Finally, we wish to thank Johann Zaller and Julia Seeber for important comments on the manuscript and Julliane de Oliveira Rüdisser for language revision.

Conflicts of Interest: The authors declare no conflict of interest.

\section{References}

1. Darwin, C. The Formation of Vegetable Mould, Through the Action of Worms with Observations on Their Habits; John Murray: London, UK, 1881.

2. Jones, C.G.; Lawton, J.H.; Shachak, M. Organisms as Ecosystem Engineers. OIKOS 1994, 69, 373-386. [CrossRef]

3. Bartlett, M.D.; Briones, M.J.I.; Neilson, R.; Schmidt, O.; Spurgeon, D.; Creamer, R.E. A critical review of current methods in earthworm ecology: From individuals to populations. Eur. J. Soil Biol. 2010, 46, 67-73. [CrossRef]

4. Blouin, M.; Sery, N.; Cluzeau, D.; Brun, J.-J.; Bédécarrats, A. Balkanized Research in Ecological Engineering Revealed by a Bibliometric Analysis of Earthworms and Ecosystem Services. Environ. Manag. 2013, 52, 309-320. [CrossRef] [PubMed]

5. Fusaro, S.; Gavinelli, F.; Lazzarini, F.; Paoletti, M.G. Soil Biological Quality Index based on earthworms (QBS-e). A new way to use earthworms as bioindicators in agroecosystems. Ecol. Indic. 2018, 93, 1276-1292. [CrossRef]

6. Doran, J.W.; Zeiss, M.R. Soil health and sustainability: Managing the biotic component of soil quality. Appl. Soil Ecol. 2000, 15, 3-11. [CrossRef]

7. Kibblewhite, M.G.; Ritz, K.; Swift, M.J. Soil health in agricultural systems. Philos. Trans. R. Soc. B 2008, 363, 685-701. [CrossRef]

8. Paoletti, M.G. The role of earthworms for assessment of sustainability and as bioindicators. Agric. Ecosyst. Environ. 1999, 74, 137-155. [CrossRef] 
9. Bispo, A.; Cluzeau, D.; Creamer, R.; Dombos, M.; Graefe, U.; Krogh, P.H.; Sousa, J.P.; Peres, G.; Rutgers, M.; Winding, A.; et al. Indicators for Monitoring Soil Biodiversity. Integr. Environ. Assess. Manag. 2009, 5, 717-719. [CrossRef]

10. Turbé, A.; De Toni, A.; Benito, P.; Lavelle, P.; Ruiz, N.; Van der Putten, W.H.; Labouze, E.; Mudgal, S. Soil Biodiversity: Functions, Threats and Tools for Policy Makers; Report for European Commission; DG Environment: Brussels, Belgium, 2010.

11. Van Groenigen, J.W.; Lubbers, I.M.; Vos, H.M.J.; Brown, G.G.; de Deyn, G.B.; van Groenigen, K.J. Earthworms increase plant production: A meta-analysis. Sci. Rep. 2014, 4, 6365. [CrossRef]

12. Boag, B.; Palmer, L.F.; Neilson, R.; Legg, R.; Chambers, S.J. Distribution, prevalence and intensity of earthworm populations in arable land and grassland in Scotland. Ann. Appl. Biol. 1997, 130, 153-165. [CrossRef]

13. Paoletti, M.G.; Sommaggio, D.; Favretto, M.R.; Petruzzelli, G.; Pezzarossa, B.; Barbafieri, M. Earthworms as useful bioindicators of agroecosystem sustainability in orchards and vineyards with different inputs. Appl. Soil Ecol. 1998, 10, 137-150. [CrossRef]

14. Phillips, H.R.P.; Guerra, C.A.; Bartz, M.L.C.; Briones, M.J.I.; Brown, G.; Crowther, T.W.; Ferlian, O.; Gongalsky, K.B.; van den Hoogen, J.; Krebs, J.; et al. Global distribution of earthworm diversity. Science 2019, 366, 480. [CrossRef] [PubMed]

15. Smith, A.C.; Harrison, P.A.; Pérez Soba, M.; Archaux, F.; Blicharska, M.; Egoh, B.N.; Erős, T.; Fabrega Domenech, N.; György, Á.; Haines-Young, R.; et al. How natural capital delivers ecosystem services: A typology derived from a systematic review. Ecosyst. Serv. 2017, 26, 111-126. [CrossRef]

16. Smith, R.G.; McSwiney, C.P.; Grandy, A.S.; Suwanwaree, P.; Snider, R.M.; Robertson, G.P. Diversity and abundance of earthworms across an agricultural land-use intensity gradient. Soil Tillage Res. 2008, 100, 83-88. [CrossRef]

17. Rutgers, M.; van Wijnen, H.J.; Schouten, A.J.; Mulder, C.; Kuiten, A.M.P.; Brussaard, L.; Breure, A.M. A method to assess ecosystem services developed from soil attributes with stakeholders and data of four arable farms. Sci. Total Environ. 2012, 415, 39-48. [CrossRef]

18. Spurgeon, D.; Keith, A.; Schmidt, O.; Lammertsma, D.; Faber, J. Land-use and land-management change: Relationships with earthworm and fungi communities and soil structural properties. BMC Ecol. 2013, 13, 46. [CrossRef]

19. Keith, A.M.; Robinson, D.A. Earthworms as Natural Capital: Ecosystem Service Providers in Agricultural Soils. Economol. J. 2012, 2,91-99.

20. Dominati, E.; Patterson, M.; Mackay, A. A framework for classifying and quantifying the natural capital and ecosystem services of soils. Ecol. Econ. 2010, 69, 1858-1868. [CrossRef]

21. Haida, C.; Rüdisser, J.; Tappeiner, U. Ecosystem services in mountain regions: Experts' perceptions and research intensity. Reg. Environ. Chang. 2015, 1-16. [CrossRef]

22. Robinson, D.A.; Hockley, N.; Dominati, E.; Lebron, I.; Scow, K.M.; Reynolds, B.; Emmett, B.A.; Keith, A.M.; de Jonge, L.W.; Schjønning, P.; et al. Natural Capital, Ecosystem Services, and Soil Change: Why Soil Science Must Embrace an Ecosystems Approach. Vadose Zone J. 2012, 11. [CrossRef]

23. Wardle, D.A.; Bardgett, R.D.; Klironomos, J.N.; Setala, H.; Van der Putten, W.H.; Wall, D.H. Ecological Linkages Between Aboveground and Belowground Biota. Science 2004, 304, 1629-1633. [CrossRef] [PubMed]

24. Shipitalo, M.; Le Bayon, R.-C. Quantifying the Effects of Earthworms on Soil Aggregation and Porosity. In Earthworm Ecology, 2nd ed.; Edwards, C.A., Ed.; CRC Press: Boca Raton, FL, USA, 2004; pp. 183-200, ISBN 9780849318191.

25. Johnston, A.S.; Sibly, R.M.; Hodson, M.E.; Alvarez, T.; Thorbek, P. Effects of agricultural management practices on earthworm populations and crop yield: Validation and application of a mechanistic modelling approach. J. Appl. Ecol. 2015, 52, 1334-1342. [CrossRef]

26. Brussaard, L. Ecosystem Services Provided by the Soil Biota. In Soil Ecology and Ecosystem Services, 1st ed.; Wall, D.H., Ed.; Oxford University Press: Oxford, UK, 2012; pp. 45-58, ISBN 9780199575923.

27. Luck, G.W.; Harrington, R.; Harrison, P.A.; Kremen, C.; Berry, P.M.; Bugter, R.; Dawson, T.R.; de Bello, F.; Díaz, S.; Feld, C.K.; et al. Quantifying the Contribution of Organisms to the Provision of Ecosystem Services. BioScience 2009, 59, 223-235. [CrossRef]

28. Hooper, D.U.; Chapin, F.S., III; Ewel, J.J.; Hector, A.; Inchausti, P.; Lavorel, S.; Lawton, J.H.; Lodge, D.M.; Loreau, M.; Naeem, S.; et al. Effects of Biodiversity on Ecosystem Functioning: A Consensus of Current Knowledge. Ecol. Monogr. 2005, 75, 3-35. [CrossRef]

29. Blouin, M.; Hodson, M.E.; Delgado, E.A.; Baker, G.; Brussaard, L.; Butt, K.R.; Dai, J.; Dendooven, L.; Peres, G.; Tondoh, J.E.; et al. A review of earthworm impact on soil function and ecosystem services. Eur. J. Soil Sci. 2013, 64, 161-182. [CrossRef]

30. Barrios, E. Soil biota, ecosystem services and land productivity. Ecol. Econ. 2007, 64, 269-285. [CrossRef]

31. ASTAT. Statistisches Jahrbuch für Südtirol. Annuario Statistico della Provincia di Bolzano; ASTAT: Bolzano, Italy, 2014.

32. IUSS Working Group WRB. World Reference Base for Soil Resources 2014, Update 2015. International Soil Classification System for Naming Soils and Creating Legends for Soil Maps; FAO: Rome, Italy, 2014; ISBN 978-92-5-108370-3.

33. Meyer, E. Bodenzoologische Untersuchungen im Rahmen des Projektes "International Cooperative Programme on Assessment and Monitoring of Air Pollution Effects on Forests" im Auftrag des Forstwirtschaftsinspektorats Bozen und des I'Istituto Agrario di San Michele all'Adige (Settore Foreste Ambiente). Bericht über Arbeiten und Ergebnisse aus dem Jahr 1993; University of Innsbruck: Innsbruck, Austria, 1994.

34. Rüdisser, J.; Tasser, E.; Peham, T.; Meyer, E.; Tappeiner, U. The dark side of biodiversity: Spatial application of the biological soil quality indicator (BSQ). Ecol. Indic. 2015, 53, 240-246. [CrossRef]

35. Haines-Young, R.H.; Potschin, M.B. Methodologies for Defining and Assessing Ecosystem Services. Final Report; Project Code C08-0170-0062; University of Nottingham: Nottingham, UK, 2009. 
36. De Groot, R.S.; Alkemade, R.; Braat, L.; Hein, L.; Willemen, L. Challenges in integrating the concept of ecosystem services and values in landscape planning, management and decision making. Ecol. Complex. 2010, 7, 260-272. [CrossRef]

37. Boyd, J.; Banzhaf, S. What are ecosystem services? The need for standardized environmental accounting units. Ecol. Econ. 2007, 63, 616-626. [CrossRef]

38. Fisher, B.; Turner, R. Ecosystem services: Classification for valuation. Biol. Conserv. 2008, 141, 1167-1169. [CrossRef]

39. Burkhard, B.; Kroll, F.; Nedkov, S.; Müller, F. Mapping ecosystem service supply, demand and budgets. Ecosyst. Serv. 2012, 21, 17-29. [CrossRef]

40. Crossman, N.D.; Burkhard, B.; Nedkov, S.; Willemen, L.; Petz, K.; Palomo, I.; Drakou, E.G.; Martín-Lopez, B.; McPhearson, T.; Boyanova, K.; et al. A blueprint for mapping and modelling ecosystem services. Ecosyst. Serv. 2013, 4, 4-14. [CrossRef]

41. Bouché, M.B. Strategies lombriciennes. Ecol. Bull. 1977, 122-132. [CrossRef]

42. Curry, J.P. Functional interactions between earthworms, microorganisms, organic matter, and plants. In Earthworm Ecology, 2nd ed.; Edwards, C.A., Ed.; CRC Press: Boca Raton, FL, USA, 2004; ISBN 9780849318191.

43. Webb, C.T.; Hoeting, J.A.; Ames, G.M.; Pyne, M.I.; LeRoy Poff, N. A structured and dynamic framework to advance traits-based theory and prediction in ecology. Ecol. Lett. 2010, 13, 267-283. [CrossRef] [PubMed]

44. Briones, M.J. Soil fauna and soil functions: A jigsaw puzzle. Front. Environ. Sci. 2014, 2. [CrossRef]

45. Lee, K.E. Earthworms. Their Ecology and Relationships with Soils and Land Use; Academic Press: Orlando, FL, USA, 1985; ISBN 0124408605.

46. Bernard, L.; Chapuis-Lardy, L.; Razafimbelo, T.; Razafindrakoto, M.; Pablo, A.-L.; Legname, E.; Poulain, J.; Bruls, T.; O’Donohue, M.; Brauman, A.; et al. Endogeic earthworms shape bacterial functional communities and affect organic matter mineralization in a tropical soil. ISME J. 2012, 6, 213-222. [CrossRef]

47. Edwards, C.A.; Bohlen, P.J. Biology and Ecology of Earthworms, 3rd ed.; Chapman \& Hall: London, UK, 1996 ; ISBN 0412561603.

48. Lavelle, P.; Spain, A. Soil Ecology. Springer: Dordrecht, The Netherlands, 2005; ISBN 978-0-7923-7123-6.

49. Römbke, J.; Jansch, S.; Didden, W. The use of earthworms in ecological soil classification and assessment concepts. Ecotoxicol. Environ. Saf. 2005, 62, 249-265. [CrossRef]

50. Brown, G.G.; Edwards, C.A.; Brussaard, L. How Earthworms Affect Plant Growth: Burrowing into the Mechanism. In Earthworm Ecology, 2nd ed.; Edwards, C.A., Ed.; CRC Press: Boca Raton, FL, USA, 2004; pp. 13-42, ISBN 9780849318191.

51. Fischer, C.; Roscher, C.; Jensen, B.; Eisenhauer, N.; Baade, J.; Attinger, S.; Scheu, S.; Weisser, W.W.; Schumacher, J.; Hildebrandt, A. How Do Earthworms, Soil Texture and Plant Composition Affect Infiltration along an Experimental Plant Diversity Gradient in Grassland? PLoS ONE 2014, 9, e98987. [CrossRef]

52. Van Schaik, L.; Palm, J.; Klaus, J.; Zehe, E.; Schröder, B. Linking spatial earthworm distribution to macropore numbers and hydrological effectiveness. Ecohydrology 2014, 7, 401-408. [CrossRef]

53. Andriuzzi, W.; Pulleman, M.; Schmidt, O.; Faber, J.; Brussaard, L. Anecic earthworms (Lumbricus terrestris) alleviate negative effects of extreme rainfall events on soil and plants in field mesocosms. Plant Soil 2015, 1-11. [CrossRef]

54. Porter, J.; Costanza, R.; Sandhu, H.; Sigsgaard, L.; Wratten, S. The Value of Producing Food, Energy, and Ecosystem Services within an Agro-Ecosystem. Ambio 2009, 38, 186-193. [CrossRef] [PubMed]

55. Sandhu, H.S.; Wratten, S.D.; Cullen, R.; Case, B. The future of farming: The value of ecosystem services in conventional and organic arable land. An experimental approach. Ecol. Econ. 2008, 64, 835-848. [CrossRef]

56. Simonsen, J.; Posner, J.; Rosemeyer, M.; Baldock, J. Endogeic and anecic earthworm abundance in six Midwestern cropping systems. Appl. Soil Ecol. 2010, 44, 147-155. [CrossRef]

57. Van Zwieten, L.; Rust, J.; Kingston, T.; Merrington, G.; Morris, S. Influence of copper fungicide residues on occurrence of earthworms in avocado orchard soils. Sci. Total Environ. 2004, 329, 29-41. [CrossRef] [PubMed]

58. Komárek, M.; Čadková, E.; Chrastný, V.; Bordas, F.; Bollinger, J.-C. Contamination of vineyard soils with fungicides: A review of environmental and toxicological aspects. Environ. Int. 2010, 36, 138-151. [CrossRef] [PubMed]

59. Winter, S.; Bauer, T.; Strauss, P.; Kratschmer, S.; Paredes, D.; Popescu, D.; Landa, B.; Guzmán, G.; Gómez, J.A.; Guernion, M.; et al. Effects of vegetation management intensity on biodiversity and ecosystem services in vineyards: A meta-analysis. J. Appl. Ecol. 2018, 55, 2484-2495. [CrossRef] [PubMed]

60. Buchholz, J.; Querner, P.; Paredes, D.; Bauer, T.; Strauss, P.; Guernion, M.; Scimia, J.; Cluzeau, D.; Burel, F.; Kratschmer, S.; et al. Soil biota in vineyards are more influenced by plants and soil quality than by tillage intensity or the surrounding landscape. Sci. Rep. 2017, 7, 17445. [CrossRef]

61. Paiola, A.; Assandri, G.; Brambilla, M.; Zottini, M.; Pedrini, P.; Nascimbene, J. Exploring the potential of vineyards for biodiversity conservation and delivery of biodiversity-mediated ecosystem services: A global-scale systematic review. Ecosyst. Funct. Ecosyst. Serv. Biodivers. Ecol. Risk Assess. 2020, 706, 135839. [CrossRef]

62. Stellin, F.; Gavinelli, F.; Stevanato, P.; Concheri, G.; Squartini, A.; Paoletti, M.G. Effects of different concentrations of glyphosate (Roundup $360^{\circledR}$ ) on earthworms (Octodrilus complanatus, Lumbricus terrestris and Aporrectodea caliginosa) in vineyards in the North-East of Italy. Appl. Soil Ecol. 2018, 123, 802-808. [CrossRef]

63. Zaller, J.G.; Heigl, F.; Ruess, L.; Grabmaier, A. Glyphosate herbicide affects belowground interactions between earthworms and symbiotic mycorrhizal fungi in a model ecosystem. Sci. Rep. 2014, 4, 5634. [CrossRef]

64. Gaupp-Berghausen, M.; Hofer, M.; Rewald, B.; Zaller, J.G. Glyphosate-based herbicides reduce the activity and reproduction of earthworms and lead to increased soil nutrient concentrations. Sci. Rep. 2015, 5, 12886. [CrossRef] [PubMed] 
65. Lavelle, P.; Rodríguez, N.; Arguello, O.; Bernal, J.; Botero, C.; Chaparro, P.; Gómez, Y.; Gutiérrez, A.; Hurtado, M.d.P.; Loaiza, S.; et al. Soil ecosystem services and land use in the rapidly changing Orinoco River Basin of Colombia. Agric. Ecosyst. Environ. 2014, 185, 106-117. [CrossRef]

66. Palm, J.; van Schaik, N.L.M.B.; Schröder, B. Modelling distribution patterns of anecic, epigeic and endogeic earthworms at catchment-scale in agro-ecosystems. Pedobiologia 2013, 56, 23-31. [CrossRef]

67. Birkhofer, K.; Schöning, I.; Alt, F.; Herold, N.; Klarner, B.; Maraun, M.; Marhan, S.; Oelmann, Y.; Wubet, T.; Yurkov, A.; et al. General Relationships between Abiotic Soil Properties and Soil Biota across Spatial Scales and Different Land-Use Types. PLoS ONE 2012, 7, e43292. [CrossRef]

68. Jaensch, S.; Steffens, L.; Hoefer, H.; Horak, F.; Ross-Nickoll, M.; Russell, D.; Toschki, A.; Roembke, J. State of knowledge of earthworm communities in German soils as a basis for biological soil quality assessment. Soil Org. 2013, 85, $215-233$.

69. Tsiafouli, M.A.; Thébault, E.; Sgardelis, S.P.; de Ruiter, P.C.; Van der Putten, W.H.; Birkhofer, K.; Hemerik, L.; de Vries, F.T.; Bardgett, R.D.; Brady, M.V.; et al. Intensive agriculture reduces soil biodiversity across Europe. Glob. Chang. Biol. 2015, 21, 973-985. [CrossRef]

70. De Vries, F.T.; Thébault, E.; Liiri, M.; Birkhofer, K.; Tsiafouli, M.A.; Bjørnlund, L.; Bracht Jørgensen, H.; Brady, M.V.; Christensen, S.; de Ruiter, P.C.; et al. Soil food web properties explain ecosystem services across European land use systems. Proc. Natl. Acad. Sci. USA 2013, 110, 14296-14301. [CrossRef]

71. Griffiths, B.; Faber, J.; Bloem, J. Applying Soil Health Indicators to Encourage Sustainable Soil Use: The Transition from Scientific Study to Practical Application. Sustainability 2018, 10, 3021. [CrossRef]

72. Zúñiga, M.C.; Feijoo, M.A.; Quintero, H.; Aldana, N.J.; Carvajal, A.F. Farmers' perceptions of earthworms and their role in soil. Appl. Soil Ecol. 2013, 69, 61-68. [CrossRef]

73. Velasquez, E.; Lavelle, P. Soil macrofauna as an indicator for evaluating soil based ecosystem services in agricultural landscapes. Acta Oecol. 2019, 100, 103446. [CrossRef]

74. Fründ, H.-C.; Graefe, U.; Tischer, S. Earthworms as Bioindicators of Soil Quality. In Biology of Earthworms; Karaca, A., Ed.; Springer: Berlin/Heidelberg, Germany, 2011; pp. 261-278, ISBN 978-3-642-14635-0.

75. Pulleman, M.; Creamer, R.; Hamer, U.; Helder, J.; Pelosi, C.; Pérès, G.; Rutgers, M. Soil biodiversity, biological indicators and soil ecosystem services-An overview of European approaches. Curr. Opin. Environ. Sustain. 2012, 4, 529-538. [CrossRef]

76. Griffiths, B.S.; Römbke, J.; Schmelz, R.M.; Scheffczyk, A.; Faber, J.H.; Bloem, J.; Pérès, G.; Cluzeau, D.; Chabbi, A.; Suhadolc, M.; et al. Selecting cost effective and policy-relevant biological indicators for European monitoring of soil biodiversity and ecosystem function. Ecol. Indic. 2016, 69, 213-223. [CrossRef]

77. Stone, D.; Ritz, K.; Griffiths, B.G.; Orgiazzi, A.; Creamer, R.E. Selection of biological indicators appropriate for European soil monitoring. Appl. Soil Ecol. 2016, 97, 12-22. [CrossRef]

78. Rutgers, M.; Orgiazzi, A.; Gardi, C.; Römbke, J.; Jänsch, S.; Keith, A.M.; Neilson, R.; Boag, B.; Schmidt, O.; Murchie, A.K.; et al. Mapping earthworm communities in Europe. Appl. Soil Ecol. 2016, 97, 98-111. [CrossRef]

79. Schon, N.L.; Mackay, A.D.; Gray, R.A.; van Koten, C.; Dodd, M.B. Influence of earthworm abundance and diversity on soil structure and the implications for soil services throughout the season. Pedobiologia 2017, 62, 41-47. [CrossRef]

80. Schon, N.L.; Mackay, A.D.; Gray, R.A.; Dodd, M.B.; van Koten, C. Quantifying dung carbon incorporation by earthworms in pasture soils. Eur. J. Soil Sci. 2015, 66, 348-358. [CrossRef]

81. Pascual, U.; Termansen, M.; Hedlund, K.; Brussaard, L.; Faber, J.H.; Foudi, S.; Lemanceau, P.; Jørgensen, S.L. On the value of soil biodiversity and ecosystem services. Ecosyst. Serv. 2015, 15, 11-18. [CrossRef]

82. Jones, L.; Norton, L.; Austin, Z.; Browne, A.L.; Donovan, D.; Emmett, B.A.; Grabowski, Z.; Howard, D.C.; Jones, J.; Kenter, J.; et al. Stocks and flows of natural and human-derived capital in ecosystem services. Land Use Policy 2016, 52, 151-162. [CrossRef]

83. Adhikari, K.; Hartemink, A.E. Linking soils to ecosystem services-A global review. Geoderma 2016, 262, 101-111. [CrossRef]

84. Bender, S.F.; Wagg, C.; van der Heijden, M.G.A. An Underground Revolution: Biodiversity and Soil Ecological Engineering for Agricultural Sustainability. Trends Ecol. Evol. 2016, 31, 440-452. [CrossRef]

85. Robinson, D.A.; Fraser, I.; Dominati, E.J.; Davíðsdóttir, B.; Jónsson, J.O.G.; Jones, L.; Jones, S.B.; Tuller, M.; Lebron, I.; Bristow, K.L.; et al. On the Value of Soil Resources in the Context of Natural Capital and Ecosystem Service Delivery. Soil Sci. Soc. Am. J. 2014, 78, 685-700. [CrossRef]

86. Dominati, E.; Mackay, A.; Green, S.; Patterson, M. A soil change-based methodology for the quantification and valuation of ecosystem services from agro-ecosystems: A case study of pastoral agriculture in New Zealand. Ecol. Econ. 2014, 100, 119-129. [CrossRef]

87. De Groot, R. Function-analysis and valuation as a tool to assess land use conflicts in planning for sustainable, multi-functional landscapes: Landscapes and sustainability. Landsc. Urban Plan. 2006, 75, 175-186. [CrossRef]

88. Spangenberg, J.H.; Settele, J. Precisely incorrect? Monetising the value of ecosystem services: Ecosystem Services-Bridging Ecology, Economy and Social Sciences. Ecol. Complex. 2010, 7, 327-337. [CrossRef] 